\title{
PENINGKATAN MUTU IKAN KEUMAMAH LOIN ACEH DARI CAKALANG (Katsuwonus pelamis) MENGGUNAKAN DAUN KARI (Murraya koenigii)
}

\author{
Muhammad Nur Fajri ${ }^{\star}$, Nurjanah, Uju \\ Departemen Teknologi Hasil Perairan, Fakultas Perikanan dan Ilmu Kelautan, IPB University \\ Diterima: 17 Agustus 2021/Disetujui: 2 Desember 2021 \\ *Korespondensi: cahayafajri@apps.ipb.ac.id
}

Cara sitasi: Fajri MN, Nurjanah, Uju. 2021. Peningkatan mutu ikan keumamah loin Aceh dari cakalang (Katsuwonus pelamis) menggunakan daun kari (Murraya koenigii). Jurnal Pengolahan Hasil Perikanan Indonesia. 24(3): 347-356.

\begin{abstract}
Abstrak
Keumamah loin merupakan ikan kayu semi basah dengan pengeringan sinar matahari satu sampai dua hari, memiliki karakteristik tekstur daging yang agak lunak, aroma spesifik dan mudah mengalami kemunduran mutu. Daun kari (Murraya koenigii) banyak mengandung senyawa bioaktif yang berfungsi sebagai antioksidan. Tujuan penelitian ini adalah untuk menentukan pengaruh ekstrak daun kari, suhu, dan waktu pengeringan terhadap mutu keumamah loin dan efektivitas daun kari sebagai antioksidan. Penelitian ini menggunakan metode eksperimen rancangan acak lengkap faktorial (RALF) dengan taraf perlakuan ekstrak daun kari $(0 \%$ dan $10 \%)$, suhu $\left(40^{\circ} \mathrm{C}\right.$ dan $\left.60^{\circ} \mathrm{C}\right)$ dan waktu pengeringan $(8 \mathrm{jam}$ dan $12 \mathrm{jam})$. Parameter yang diamati kadar proksimat, nilai aktivitas air (aw) dan bilangan thiobarbituric acid (TBA). Hasil penelitian menunjukkan penggunaan daun kari, suhu, dan waktu pengeringan tidak berpengaruh terhadap kadar proksimat dan aktivitas air. Kadar protein diperoleh sebesar 28,22-32,1\%, kadar lemak $2,72-4,60 \%$, kadar abu $2,70-4,52 \%$, kadar air $35,10-50,43 \%$ dan aktivitas air $0,84-0,87$. Namun penggunaan daun kari berpengaruh terhadap bilangan TBA. Penggunaan daun kari $10 \%$, suhu $40^{\circ} \mathrm{C}$ dan waktu 8 jam merupakan perlakuan terbaik karena memiliki bilangan TBA paling rendah yaitu sebesar $0,40 \pm 0,003 \mathrm{mg}$ malonialdehida/kg. Penggunaan daun kari, suhu, dan waktu pengeringan dapat menghambat terjadinya proses oksidasi lipid pada produk keumamah loin.
\end{abstract}

Kata kunci: aktivitas air, cakalang, daun kari, keumamah loin, thiobarbituric acid

\section{Quality Improvement of Keumamah Loin Aceh Fish from Skipjack Tuna (Katsuwonus pelamis) using Curry Tree Leaves (Murraya koenigii)}

\begin{abstract}
Keumamah loin is a semi-wet wood fish with one to two days of sun drying, with soft meat texture, specific aroma and easily degradation in quality. Curry tree (Murraya koenigii) contain many bioactive compounds that serve as antioxidants. The Study was aimed to find out the effect of curry leaf extract, temperature, and drying time on the quality of keumamah loin and the effectiveness of curry tree as antioxidant. The study used complete randomized factorial design experimental method with different curry tree leaf extract levels $(0 \%$ and $10 \%)$, temperature $\left(40^{\circ} \mathrm{C}\right.$ and $\left.60^{\circ} \mathrm{C}\right)$, and time ( 8 hours and 12 hours). The observed parameters were proximate levels, water activity values (aw), and thiobarbituric acid (TBA). The results showed the use of curry tree leaves, temperature, and drying time did not have effect on proximate levels and water activity with protein $28.22-32.1 \%$, fat $2.72-4.60 \%$, ash $2.70-4.52 \%$, water $35.10-50.43 \%$ and water activity $0.84-0.87$. However, the use of curry tree leaves affects the number of thiobarbituric acid (TBA). The use of $10 \%$ curry tree leaves, $40^{\circ} \mathrm{C}$ temperature, and 8 hours is the best treatment which has the lowest TBA $0.40 \pm 0.003 \mathrm{mg}$ malondialdehyde $/ \mathrm{kg}$. The use of curry tree leaves, temperature, and drying time can inhibit the lipids oxidation process in the products of keumamah loin.
\end{abstract}

Keyword: : curry tree leaves, keumamah loin, skipjack tuna, thiobarbituric acid, water activity 


\section{PENDAHULUAN}

Aceh merupakan satu di antara provinsi di Indonesia yang memiliki sumber daya kelautan yang sangat potensial, dengan luas perairannya mencapai $295.000 \mathrm{~km}^{2}$, dengan panjang garis pantai $2.666 \mathrm{~km}$ yang memiliki potensi perikanan tangkap 165.000 ton per tahun (DKP Aceh 2019). Ketersediaan pasokan bahan baku perikanan yang melimpah di Provinsi Aceh membuka peluang yang cukup besar bagi masyarakat pesisir dalam hal meningkatkan pendapatan dan kesejahteraan (KKP 2018). Ikan cakalang (Katsuwonus pelamis) merupakan salah satu komoditas perikanan yang banyak ditemukan di Perairan Aceh selain ikan tongkol (Euthynnus affinis) dan tuna sirip kuning (Thunnus albacares) yang produksinya terus meningkat. Pada tahun 2018 hasil tangkapan jenis cakalang sebesar 20.614 ton (DKP Aceh 2019) dan pada tahun 2019 meningkat menjadi 24.239 ton (DKP Aceh 2020). Pada musim-musim tertentu, hasil tangkapan ikan-ikan pelagis ini akan melimpah, sehingga sebagiannya diolah menjadi ikan keumamah.

Keumamah juga sering disebut dengan ikan kayunya masyarakat Aceh yang diolah secara tradisional dengan bahan bakunya dari ikan cakalang, tuna, dan tongkol. Keumamah merupakan produk olahan yang telah melewati tahapan pembersihan, perebusan, penambahan garam, dan pengeringan (pengeringan awal dan pengeringan akhir). Pengeringan awal untuk mempermudah proses pemisahan tulang pada daging sehingga daging loin yang terbentuk tidak hancur. Sementara pengeringan terakhir bertujuan untuk mendapatkan produk keumamah loin yang lebih kering.

Permintaan ikan keumamah terus mengalami peningkatan. Produksi keumamah sebesar 17,44 ton/tahun pada tahun 2020 (DKP Aceh 2021). Seiring waktu permintaan ikan keumamah telah tersedia juga dalam bentuk semi basah, namun kendala yang ditemukan pada produk keumamah loin adalah mutu dan umur simpan sehingga produksinya harus disesuaikan dengan permintaan pasar. Umumnya umur simpan keumamah loin sekitar 2-3 hari penyimpanan. Hal ini sangat tergantung dari proses pengeringan yang dilakukan, pengeringan maksimal dapat mempertahankan mutu keumamah loin selama 3 hari pada suhu ruang.

Proses pengolahan keumamah loin pada umumnya dilakukan dengan sangat sederhana menggunakan sarana yang minim terutama pada saat hasil tangkapan melimpah. Proses pengolahan pada umumnya menggunakan bahan baku mutunya mulai menurun dan pengolahannya belum optimal sehingga mutu keumamah yang dihasilkan masih rendah.

Masyarakat Aceh dalam menyajikan masakan ikan dan daging pada umumnya menggunakan daun kari (Murraya koenigii) sebagai bumbu atau penyedap alami dalam masakan karena dapat memberikan rasa dan aroma yang khas pada masakan. Daun kari masih memberikam aroma khas dan rasa yang tajam walaupun sudah dikeringkan (Singh et al. 2014). Penggunaan daun kari sebagai bumbu masakan telah dilakukan secara turun temurun, misalnya masakan kari ikan paya, kari gulai ayam, kari gulai bebek, kari kambing dan kuah beulangong. Tanaman ini mudah ditemukan dan pada umumnya banyak ditanam di pekarangan rumah sebagai rempah-rempah dalam berbagai bumbu masakan.

Beberapa hasil penelitian menunjukkan bahwa daun kari mengandung senyawa antioksidan dan antibakeri yang tinggi (Baskaran et al. 2011; Fachraniah et al. 2012; Jakhar et al. 2015). Antioksidan merupakan suatu senyawa yang memiliki kemampuan untuk mencegah, menghambat proses oksidasi lipid dengan cara mengikat radikal bebas sehingga menjadi stabil. Adanya senyawa antioksidan pada produk makanan dapat mencegah dan menghambat terjadinya proses oksidasi lipid yang dapat menyebabkan ketengikan. Beberapa hasil penelitian melaporkan penggunaan daun kari dapat menghambat proses oksidasi lipid pada berbagai produk pangan (Biswas et al. 2012; Das et al. 2011; Dina et al. 2018; Restina 2014). Berdasarkan hasil penelitian tersebut, perlu dilakukan penelitian untuk meningkatkan mutu keumamah dengan cara mengoptimalkan proses pengeringan dan penambahan daun kari sebagai antioksidan. Penelitian ini bertujuan untuk menentukan 
pengaruh ekstrak daun kari, suhu, dan waktu pengeringan terhadap karakteristik mutu produk keumamah loin berdasarkan kadar proksimat, nilai aktivitas air (aw), dan bilangan thiobarbituric acid (TBA).

\section{BAHAN DAN METODE Bahan dan Alat}

Bahan-bahan penelitian yang digunakan ikan cakalang segar, ukuran $0,8 \pm 0,1 \mathrm{~kg} / \mathrm{ekor}$, panjang $28 \pm 2 \mathrm{~cm}$ yang diperoleh di Pelabuhan Perikanan Samudera (PPS) Kutaraja Lampulo Banda Aceh, daun kari segar, thiobarbituric acid (TBA) (Merck-Jerman), asam asetat glacial PA (Merck-Jerman), asam klorida (HCl) 37\% PA (Merck-Jerman), akuades, garam, dan air. Peralatan yang digunakan dalam penelitian yaitu spektrofotometer UVVis (Agilent Technologi-Cary 60), aw meter (Novasina ms1 set-aw), destilator, vorteks, sentrifuga (GEMMY-PCL-03), pisau stainless, timbangan analitik (AND GF-600 dan 1200), lempeng hangat (IKAR C-MAG HS 7), alatalat gelas (IWAKI-phyrex), kain flanel, alat kocok, timbangan analitik, dan pengangas air (GFL-1013-Jerman).

\section{Metode}

Penelitian ini terdiri dari dua tahap yaitu pembuatan larutan ekstrak cair daun kari dan pembuatan keumamah loin. Pembuatan larutan rendaman ekstrak cair daun kari menggunakan simplisia kari sebanyak $10 \%$ volume air yang diekstraksi pada suhu $70 \pm 5^{\circ} \mathrm{C}$ selama 30 menit (Fachraniah et al. 2012), ekstraksi disaring dengan kain flanel. Ekstraksi digunakan sebagai larutan perendaman. Keumamah loin dibuat menggunakan cakalang segar yang telah disiangi, difilet, dibersihkan dan dicuci dengan air bersih mengalir. Ikan direbus dengan air mendidih \pm 30 menit, dan ditiriskan \pm 2 menit. Loin ikan cakalang direndam dengan ekstrak cair daun kari $0 \%$ dan $10 \%$ selama 30 menit (Restina 2014) dengan modifikasi. Selanjutnya loin yang sudah direndam dikeringkan menggunakan oven pada suhu $40^{\circ} \mathrm{C}$ dan $60^{\circ} \mathrm{C}$ selama 8 jam dan 12 jam. Produk yang dihasilkan selanjutnya disimpan selama 3 hari pada suhu ruang, lalu dianalisis kadar proksimat, aktivitas air, dan TBA.

\section{Analisis proksimat}

Analisis proksimat berupa kadar protein, kadar lemak, kadar abu, dan kadar air, Kadar protein dianalisis dengan metode Kjeldhal mengacu pada (AOAC 2005), lemak dianalisis dengan metode sokhlet mengacu pada (AOAC 2005), kadar abu dianalisis mengacu pada (AOAC 2005), kadar air dianalisis mengacu metode termogravimetri mengacu pada (AOAC 2005).

\section{Aktivitas air (aw)}

Analisis nilai aw menggunakan metode test kit aw-meter (Novasina ms1 set-aw). Cara pengoperasian: alat dihubungkan dengan arus listrik, tekan tombol daya "on/off". kemudian alat dikalibrasi menggunakan standar SC 75. Masukkan \pm 3 g sampel yang telah dihaluskan pada wadah sampel dan biarkan sampai beberapa menit, penentuan nilai aw diperoleh dengan tercapainya tanda segitiga muncul empat buah sebagai indikator nilai pengukuran.

\section{Aktivitas bilangan TBA}

Analisis bilangan TBA mengacu metode yang digunakan oleh Apriyantono et al. (1989). Sebanyak $10 \mathrm{~g}$ sampel ditambahkan akuades sebanyak $50 \mathrm{~mL}$, lalu diblender. Sampel yang telah dihaluskan dipindahkan secara kuantitatif ke dalam labu destilasi sambil dicuci dengan 47,5 $\mathrm{mL}$ akuades. Selanjutnya, ditambahkan $\pm 2,5 \mathrm{~mL} \mathrm{HCl} 4 \mathrm{M}$ (hingga $\mathrm{pH}$ menjadi 1,5). Sampel didestilasi hingga diperoleh cairan destilat sebanyak 50 $\mathrm{mL}$. Destilat yang diperoleh diaduk hingga homogen dan dipipet ke dalam tabung reaksi bertutup sebanyak $5 \mathrm{~mL}$. Pereaksi TBA ditambahkan sebanyak $5 \mathrm{~mL}$ ( $0,02 \mathrm{M}$ dalam $90 \%$ asam asetat glasial), divorteks hingga homogen. Larutan sampel dipanaskan dalam air mendidih selama 35 menit kemudian didinginkan dengan air mengalir selama 10 menit. Larutan blanko dibuat menggunakan 5 $\mathrm{mL}$ akuades dan $5 \mathrm{~mL}$ pereaksi dengan cara yang sama seperti penetapan sampel. Larutan blangko digunakan sebagai titik nol dalam pengukuran absorbansi. Larutan sampel kemudian diukur nilai absorbansinya (D) pada panjang gelombang $528 \mathrm{~nm}$. Bilangan TBA didefinisikan sebagai mg malonaldehida/ 
kg sampel. Nilai bilangan TBA sampel dapat dihitung melalui rumus:

Bilangan TBA $=\frac{3}{\text { Berat sampel }} \times 7,8 \times \mathrm{D}$

Keterangan:

TBA: Thiobarbituric Acid (mg malonaldehid/kg sampel)

D: Nilai absorbansi pada $528 \mathrm{~nm}$

\section{Analisis Data}

Penelitian ini menggunakan Rancangan Acak Lengkap Faktorial (RALF) 3 faktor. Faktor 1 adalah penggunaan ekstrak cair daun kari dengan taraf $0 \%\left(\mathrm{~K}_{0}\right)$ dan $10 \%\left(\mathrm{~K}_{10}\right)$. Faktor 2 adalah suhu dengan taraf $40^{\circ} \mathrm{C}\left(\mathrm{S}_{40}\right)$ dan $60^{\circ} \mathrm{C}\left(\mathrm{S}_{60}\right)$. Faktor 3 adalah waktu pengeringan dengan taraf 8 jam $\left(\mathrm{W}_{8}\right)$ dan 12 jam $\left(\mathrm{W}_{12}\right)$ dengan 3 kali pengulangan. Data dianalisis menggunakan tabel sidik ragam (ANOVA) dan uji DMTR (Duncan) apabila terdapat perbedaan nyata pada perlakuan. Tingkat kepercayaan yang digunakan $95 \%$.

\section{HASIL DAN PEMBAHASAN Kadar Protein}

Kadarprotein keumamahloin dapatdilihat pada Table 1. Kadar protein pada keumamah loin sebesar $28,22 \pm 0,52 \%-32,91 \pm 0,40 \%$. Hasil analisis statistik menunjukkan interaksi daun kari, suhu, dan waktu tidak memberikan pengaruh nyata terhadap kadar protein keumamah loin $(p>0,05)$, Namun perlakuan daun kari, suhu, waktu, dan interaksi kari suhu memberikan pengaruh signifikan terhadap kadar protein $(p<0,05)$. Daun kari memiliki kandungan protein (Abeysinghe et al. 2021; Jakhar et al. 2015) yang diduga dapat memberikan kontribusi protein pada produk keumamah loin pada saat perendaman. Interaksi daun kari dan suhu dapat meningkatkan kadar protein, hal ini diduga karena protein yang terserap pada saat perendaman loin akan semakin meningkat dengan meningkatnya suhu pengeringan yang disebabkan hilangnya sebagian air pada produk, sehingga produk menjadi pekat. Adawyah (2007) melaporkan protein di dalam bahan pangan akan meningkat seiring dengan penurunan kadar air.

Berdasarkan Table 1 kadar protein keumamah loin sekitar 28,22 $\pm 0,52 \%$ $32,91 \pm 0,40 \%$. Hasil penelitian ini lebih tinggi dari hasil penelitian Dina et al. (2018) penggunaan daun kari dengan konsentrasi berbeda pada pembuatan salted egg sauce memiliki kadar protein 9,40-9,96\%. Namun hal tersebut selaras dengan hasil penelitian Ulafaturriza et al. (2019) bahwa kadar protein keumamah kering sebesar 27,87\% dan lebih rendah bila dibandingkan dengan hasil penelitian Pundoko et al. (2014) kandungan protein ikan kayu cakalang sebesar $67,55 \%$ dan kandungan protein ikan kayu cakalang sebesar 54,79\% (Nabila et al. 2017), hal ini disebabkan karena perbedaan bahan baku dan karakteristik produk.

Table 1 The chemical compositon of keumamah loin

\begin{tabular}{lcccc}
\hline \multirow{2}{*}{ Treatment } & \multicolumn{4}{c}{ Composition (\%) } \\
\cline { 2 - 5 } & Protein & Lipid & Ash & Water \\
\hline $\mathrm{K}_{0} \mathrm{~S}_{40} \mathrm{~W}_{8}$ & $28.22 \pm 0.52^{\mathrm{a}}$ & $2.72 \pm 0.63^{\mathrm{a}}$ & $2.94 \pm 0.10^{\mathrm{a}}$ & $50.06 \pm 0.35^{\mathrm{a}}$ \\
$\mathrm{K}_{0} \mathrm{~S}_{40} \mathrm{~W}_{12}$ & $28.99 \pm 0.37^{\mathrm{a}}$ & $3.32 \pm 0.47^{\mathrm{a}}$ & $3.36 \pm 0.39^{\mathrm{a}}$ & $41.31 \pm 0.42^{\mathrm{a}}$ \\
$\mathrm{K}_{0} \mathrm{~S}_{60} \mathrm{~W}_{8}$ & $31.34 \pm 0.40^{\mathrm{a}}$ & $3.44 \pm 0.52^{\mathrm{a}}$ & $3.77 \pm 0.14^{\mathrm{a}}$ & $43.06 \pm 0.35^{\mathrm{a}}$ \\
$\mathrm{K}_{0} \mathrm{~S}_{60} \mathrm{~W}_{12}$ & $32.86 \pm 0.32^{\mathrm{a}}$ & $3.67 \pm 0.32^{\mathrm{a}}$ & $4.52 \pm 0.13^{\mathrm{a}}$ & $35.69 \pm 2.83^{\mathrm{a}}$ \\
$\mathrm{K}_{10} \mathrm{~S}_{40} \mathrm{~W}_{8}$ & $28.59 \pm 0.41^{\mathrm{a}}$ & $3.12 \pm 0.24^{\mathrm{a}}$ & $2.70 \pm 0.46^{\mathrm{a}}$ & $50.43 \pm 2.31^{\mathrm{a}}$ \\
$\mathrm{K}_{10} \mathrm{~S}_{40} \mathrm{~W}_{12}$ & $30.62 \pm 0.68^{\mathrm{a}}$ & $4.60 \pm 0.34^{\mathrm{a}}$ & $2.97 \pm 0.50^{\mathrm{a}}$ & $39.09 \pm 0.33^{\mathrm{a}}$ \\
$\mathrm{K}_{10} \mathrm{~S}_{60} \mathrm{~W}_{8}$ & $31.22 \pm 0.51^{\mathrm{a}}$ & $3.26 \pm 0.62^{\mathrm{a}}$ & $3.05 \pm 0.71^{\mathrm{a}}$ & $43.98 \pm 0.18^{\mathrm{a}}$ \\
$\mathrm{K}_{10} \mathrm{~S}_{60} \mathrm{~W}_{12}$ & $32.91 \pm 0.40^{\mathrm{a}}$ & $4.04 \pm 0.30^{\mathrm{a}}$ & $4.17 \pm 0.34^{\mathrm{a}}$ & $35.10 \pm 0.47^{\mathrm{a}}$ \\
\hline Note: $\mathrm{K}:$ curry (\%), S: temperature ( $\left.{ }^{\circ} \mathrm{C}\right), \mathrm{W}:$ time (hours); \\
a letters that follow numbers in the same column indicate no significant difference $(p>0.05)$
\end{tabular}




\section{Kadar Lemak}

Kadar lemak keumamah loin dapat dilihat pada Table 1. Kadar lemak pada keumamah loin sebesar $2,72 \pm 0,63 \%-4,60 \pm 0,34 \%$. Hasil uji statistik menunjukkan perlakuan daun kari, suhu, dan waktu tidak memberikan pengaruh nyata terhadap kadar lemak keumamah loin $(p>0,05)$, namun perlakuan daun kari dan waktu memberikan pengaruh terhadap kadar lemak $(p<0,05)$. Daun kari yang mengandung lemak (Abeysinghe et al. 2021) diduga terserap loin pada saat proses perendaman, hal ini disebabkan pada saat perendaman kondisi loin dan cairan ekstrak masih panas sehingga proses penyerapan lebih maksimal karena viskositas rendah. Sementara faktor waktu dapat memengaruhi lamanya bahan mengalami proses pengeringan. Semakin lama waktu pengeringan, tingkat kepekatan produk semakin tinggi, sehingga kadar lemak akan meningkat.

Berdasarkan Table 1 kadar lemak keumamah loin sekitar 2,72 $\pm 0,63 \%$ $4,60 \pm 0,34 \%$. Hasil penelitian ini selaras dengan penelitian Dina et al. (2018) bahwa penggunaan daun kari dengan konsentrasi berbeda pada pembuatan salted egg sauce memiliki kadar lemak 3,39-3,79\%. Pundoko et al. (2014) melaporkan kandungan lemak ikan kayu cakalang sebesar 3,99\% dan kandungan lemak ikan kayu cakalang sebesar 4,07\% (Nabila et al. 2017).

Hasil penelitian menunjukkan penggunaan daun kari berpengaruh nyata terhadap kadar lemak produk keumamah loin, hal ini berbeda dengan hasil penelitian Dina et al. (2018) yaitu penambahan daun kari pada pembuatan salted egg sauce tidak memberikan pengaruh terhadap kadar lemak, hal ini diduga karena konsentrasi daun kari yang digunakan masih sangat rendah.

\section{Kadar Abu}

Kadar abu keumamah loin dapat dilihat pada Table 1. Kadar abu pada keumamah

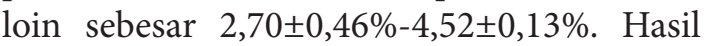
analisis statistik menunjukkan kombinasi perlakuan ekstrak kari, suhu, dan waktu tidak memberikan pengaruh nyata terhadap kadar abu keumamah loin $(p>0,05)$, namun perlakuan daun kari, suhu, dan waktu memberikan pengaruh signifikan terhadap kadar abu $(p<0,05)$. Daun kari dapat memengaruhi kadar abu karena daun kari mengandung komponen mineral (Abeysinghe et al. 2021). Perlakuan suhu pengeringan dapat menguapkan air pada produk sehingga produk menjadi pekat, sementara waktu dapat memengaruhi lamanya bahan mengalami proses pengeringan, sehingga akan memengaruhi tingkat kepekatan produk yang dapat meningkatkan kadar abu. Riansyah et al. (2013) melaporkan semakin meningkatnya suhu dan lamanya waktu pengeringan dapat meningkatkan nilai kadar abu.

Hasil penelitian kadar abu keumamah loin sebesar 2,70 $\pm 0,46 \%-4,52 \pm 0,13 \%$. Hasil ini lebih tinggi dibandingkan dengan penelitian Sulaiman (2014) yang melaporkan kadar abu keumamah yang dikeringkan dengan oven pada suhu $70^{\circ} \mathrm{C}$ selama 22 jam memiliki kadar abu sebesar $1,58 \%$ (bb). Nabila et al. (2017) melaporkan kandungan abu ikan kayu cakalang sebesar 0,96\% dan hasil penelitian Dina et al. (2018) penggunaan daun kari dengan kosentrasi berbeda pada pembuatan salted egg sauce memiliki kadar abu sebesar 1,94-2,04\%.

Berdasarkanhasilpenelitianmenunjukkan faktor daun kari berpengaruh terhadap kadar abu. Hasil ini sejalan dengan penelitian Dina et al. (2018) menyatakan penambahan daun kari pada pembuatan salted egg sauce memberikan pengaruh terhadap kadar abu, hal ini diduga daun kari yang mengandung mineral (Abeysinghe et al. 2021) terabsorbsi pada saat perendaman keumamah loin.

\section{Kadar Air}

Kadar air keumamah loin dapat dilihat pada Table 1. Kadar air pada keumamah loin sebesar $35,10 \pm 0,47 \%-50,43 \pm 2,31 \%$. Hasil analisis statistik menunjukkan kombinasi perlakuan daun kari, suhu, dan waktu tidak memberikan pengaruh nyata terhadap kadar air keumamah loin $(p>0,05)$. Namun perlakuan suhu dan waktu memberi pengaruh yang sangat signifikan terhadap kadar air $(\mathrm{p}<0,05)$. Suhu dapat memengaruhi cepat lambatnya proses penguapan pada produk. Semakin tinggi suhu yang digunakan proses 
penguapan akan semakin cepat terjadi. Winarno (1991) menyatakan bahwa semakin tinggi suhu pengeringan proses penguapan semakin cepat, sehingga kandungan air bahan akan semakin rendah. Sementara perlakuan waktu dapat memengaruhi lamanya bahan mengalami proses pengeringan, sehingga akan memengaruhi tingkat kepekatan produk. Kadar air dapat memengaruhi stabilitas dan kualitas produk, semakin tinggi kadar air produk pangan, maka produk akan sangat mudah mengalami kemunduran mutu. Jika kadar air tinggi proses kemunduran mutu pada produk akan cepat terjadi akibat aktivitas mikrob (Kusnandar 2010). Hernando et al. (2015) menyatakan pertumbuhan bakteri akan terhambat dengan kadar air yang rendah sehingga daya tahan produk akan bertahan lebih lama.

Hasil penelitian kadar air keumamah loin sebesar 35,10\%-50,43\% menunjukkan kadar air yang lebih tinggi dibandingkan dengan penelitian Restina (2014) yaitu kadar air keumamah pada perendaman 30 dan 60 menit dengan ekstrak etanol kari $60 \mu \mathrm{l}$ dan $90 \mu \mathrm{l}$ memiliki kadar air sebesar 25,03$30,01 \%$. Sulaiman (2014) melaporkan kadar air keumamah yang dikeringkan dengan oven menggunakan suhu $70^{\circ} \mathrm{C}$ selama 22 jam memiliki kadar air sebesar $15,57 \%$ (bb). Begitu juga hasil penelitian Pundoko et al. (2014) yaitu kandungan air ikan kayu cakalang sebesar 22,50\%, serta Nabila et al. (2017) yaitu kadar air ikan kayu cakalang sebesar $11 \%$.

Perbedaan kadar air ini disebabkan karena perbedaan proses pengolahan pada tahap pengeringan, misalnya suhu dan lamanya waktu pengeringan. Semakin tinggi suhu dan waktu pengeringan dapat menyebabkan kehilangan air pada bahan semakin besar (Adawiyah 2007). Winarno (1991) menyatakan semakin tinggi suhu pengeringan maka akan semakin cepat terjadi penguapan, sehingga kandungan air di dalam bahan akan semakin rendah. Rachmawan (2001) menyatakan proses pengeringan akan semakin cepat terjadi dengan suhu dan kecepatan aliran udara yang semakin meningkat. Semakin tinggi suhu udara pengeringan, besar energi panas yang dibawa udara sehingga semakin besar jumlah massa cairan yang diuapkan dari permukaan bahan yang dikeringkan. Sementara itu, perlakuan waktu dapat memengaruhi lamanya bahan mengalami proses pengeringan sehingga akan memengaruhi tingkat kepekatan produk.

Kadar air keumamah loin berkisar 35,10$50,43 \%$. Hal tersebut mengindikasikan produk ini merupakan produk semibasah yang sangat rentan terhadap kemunduran mutu. Kadar air dalam bahan pangan dapat memengaruhi stabilitas dan kualitas produk, sehingga dapat memengaruhi cepat atau lambat terjadinya kemunduran mutu. Semakin tinggi kandungan air pada suatu bahan, maka aktivitas mikrob akan semakin meningkat sehingga produk akan cepat mengalami kemunduran mutu. Hernando et al. (2015) melaporkan pertumbuhan bakteri akan terhambat dengan kadar air yang rendah sehingga daya tahan produk akan bertahan lebih lama, namun jika kadar air tinggi proses kemunduran mutu pada produk akan cepat terjadi akibat aktivitas mikroba (Kusnandar 2010).

\section{Aktivitas Air $\left(a_{w}\right)$}

Nilai aktivitas air $\left(\mathrm{a}_{\mathrm{w}}\right)$ keumamah loin dapat dilihat pada Figure 1. Nilai aktivitas air $(\mathrm{a} w)$ keumamah loin sebesar $0,838 \pm 0,001$ $0,866 \pm 0,001$. Hasil analisis statistik menunjukkan perlakuan daun kari, suhu, dan waktu tidak memberikan pengaruh nyata terhadap nilai $\mathrm{a}_{\mathrm{w}}$ keumamah loin $(p>0,05)$. Namun faktor daun kari, suhu, waktu, dan interaksi suhu waktu berpengaruh signifikan terhadap nilai $a_{w}(p<0,05)$. Interaksi suhu waktu dapat memengaruhi nilai $a_{w}$. Hal ini diduga karena hilangnya sebagian air bebas yang terdapat pada produk keumamah loin pada saat pengeringan sehingga memengaruhi nilai aktivitas air. Semakin tinggi suhu dan lama waktu pengeringan dapat mengurangi kadar air bebas pada produk keumamah loin sehingga nilai $a_{w}$ akan menurun. Proses pengeringan merupakan salah satu cara untuk menurunkan nilai aktivitas air (Belitz et al. 2009).

Hasil penelitian menunjukkan nilai $\mathrm{a}_{\mathrm{w}}$ keumamah loin sebesar 0,838 $\pm 0,001$ $0,866 \pm 0,001$. Hasil penelitian ini sejalan dengan Restina (2014) yang melaporkan bahwa nilai $\mathrm{a}_{\mathrm{w}}$ keumamah pada perendaman 


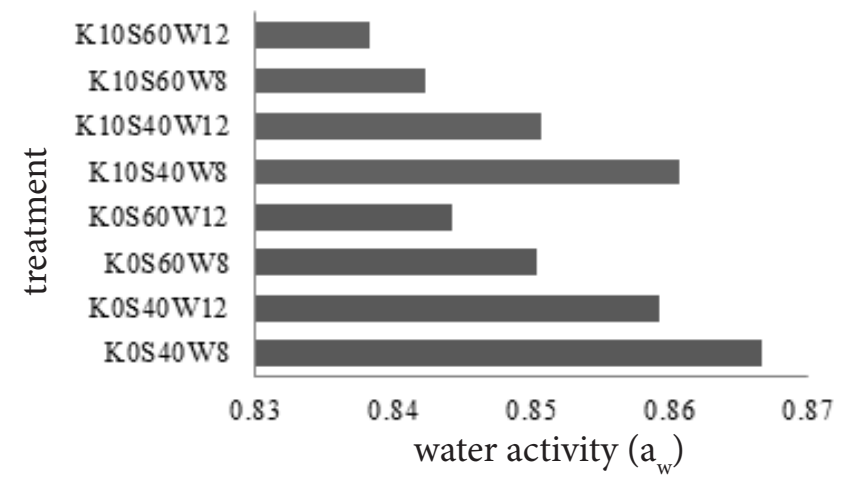

Figure 1 water activity $\left(a_{w}\right)$ of keumamah loin with different treatment

30 dan 60 menit dengan ekstrak etanol kari 60 $\mu \mathrm{L}$ dan $90 \mu \mathrm{L}$ memiliki nilai $\mathrm{a}_{\mathrm{w}}$ sebesar 0,842 0,922 . Begitu juga dengan hasil penelitian Dina et al. (2018) penggunaan daun kari dengan konsentrasi 2-8\% pada salted egg sauce memiliki nilai $\mathrm{a}_{\mathrm{w}}$ sebesar $0,835-0,841$.

Hasil penelitian menunjukkan penggunaan daun kari dapat memengaruhi nilai $a_{w}$ keumamah loin. Restina (2014) melaporkan penggunaan daun kari tidak memengaruhi nilai $a_{w}$ pada keumamah tongkol dan Dina et al. (2018) menyatakan penambahan daun kari sebanyak $2-8 \%$ pada pembuatan salted egg sauce tidak memberikan pengaruh terhadap nilai $\mathrm{a}_{\mathrm{w}}$. hal ini diduga karena konsentrasi daun kari yang digunakan masih sangat rendah. Ekstrak daun kari mampu mengikat air pada produk keumamah loin. Daun kari efektif mengurangi hilangya kadar air pada daging selama penyimpanan (Das et al. 2011).

Aktivitas air keumamah loin sekitar $0,838-0,866$. Hal ini menunjukkan produk keumamah loin mempunyai potensi yang baik untuk pertumbuhan khamir, kapang dan bakteri. Hadiwiyoto (1993) menjelaskan bahwa nilai $\mathrm{a}_{\mathrm{w}}$ merupakan salah satu unsur instrinsik pada produk pangan yang dapat mendorong pertumbuhan mikroba Comaposada et al. (2005) menjelaskan bahwa $a_{w}$ juga bisa dijadikan parameter yang dapat memprediksi kerusakan suatu bahan pangan. Fardiaz (1992) menyatakan bakteri memerlukan $\mathrm{a}_{\mathrm{w}}$ lebih dari 0,9 untuk pertumbuhannya. Sementara nilai $a_{w}$ yang berbeda akan memengaruhi pertumbuhan dan jenis mikrob yang berkembang (Winarno 1991).

\section{Bilangan TBA}

Pengaruh kombinasi perlakuan daun kari, suhu, dan waktu pengeringan terhadap bilangan TBA keumamah loin dapat dilihat pada Figure 2. Bilangan TBA pada keumamah loin berkisar antara 0,40 $\pm 0,03-1,13 \pm 0,04 \mathrm{mg}$ malonaldehida $/ \mathrm{kg}$. Hasil analisis statistik menunjukkan kombinasi perlakuan ekstrak kari, suhu, dan waktu memberikan pengaruh nyata terhadap bilangan TBA keumamah loin $(p<0,05)$, Bilangan TBA terendah pada kombinasi perlakuan ekstrak daun kari $10 \%$, suhu $40^{\circ} \mathrm{C}$ dan waktu 8 jam sebesar $0,40 \pm 0,03$ $\mathrm{mg}$ malonaldehida/kg dan tertinggi pada

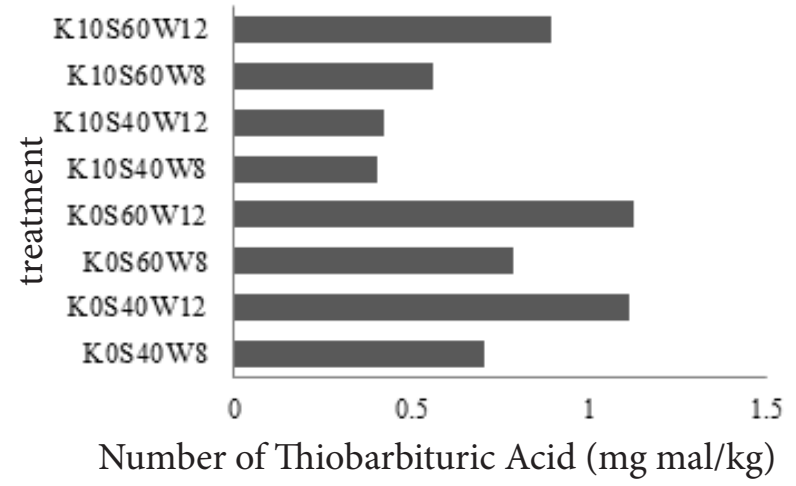

Figure 2 Number of Thiobarbituric Acid (TBA) of keumamah loin with different treatment 
perlakuan ekstrak daun kari $0 \%$, suhu $60^{\circ} \mathrm{C}$ dan waktu 12 jam sebesar $1,13 \pm 0,04 \mathrm{mg}$ malonaldehid $/ \mathrm{kg}$.

Hasil penelitian menunjukkan bahwa bilangan TBA keumamah loin sebesar $0,40 \pm 0,03-1,12 \pm 0,04 \mathrm{mg}$ malonaldehida $/ \mathrm{kg}$. Nilai TBA hasil penelitian ini hampir sama dengan penelitian Das et al. (2011) yaitu penggunaan bubuk daun kari $0,2 \%$ pada daging kambing mentah memiliki bilangan TBARS 0,65-1,12 $\mathrm{mg}$ malonaldehida $/ \mathrm{kg}$ dan pada daging kambing masak memiliki bilangan TBARS sebesar 0,36-0,89 $\mathrm{mg}$ malonaldehida $/ \mathrm{kg}$ pada penyimpanan suhu $4^{\circ} \mathrm{C}$. Sementara itu hasil penelitian Biswas et al. (2012) melaporkan penambahan ekstrak air daun kari pada daging giling babi memiliki nilai TBARS sebesar $0,662 \mathrm{mg}$ malonaldehida $/ \mathrm{kg}$ pada penyimpanan suhu $4 \pm 1^{\circ} \mathrm{C}$. Hasil penelitian ini lebih tinggi dari penelitian Dina et al. (2018) yaitu penggunaan daun kari dengan konsentrasi berbeda 2-8\% pada pembuatan salted egg sauce memiliki bilangan TBARS 0,26-0,99 mg malonaldehida/ $\mathrm{kg}$.

Hasil penelitian menunjukkan penggunaan daun kari dapat menghambat terjadinya proses oksidasi lipid. Hasil ini sejalan dengan penelitian Biswas et al. (2012) penambahan ekstrak daun kari dapat menghambat terjadinya proses oksidasi lipid pada daging babi. Penelitian Das et al. (2011) menyatakan daun kari sangat efektif sebagai penghambat oksidasi lipid pada produk daging mentah dan olahan. Begitu juga hasil penelitian Dina et al. (2018) yaitu penggunaan daun kari dapat menghambat oksidasi lipid pada pembuatan salted egg sauce. Flavanoid merupakan senyawa lain dari fenolik yang memiliki aktivitas antioksidan (Pietta 2000). Dewi et al. (2014) melaporkan flavonoid merupakan senyawa yang memiliki potensi antioksidan karena memiliki gugus hidroksil yang terikat pada karbon cincin aromatik sehingga dapat mengikat radikal bebas yang dihasilkan dari reaksi oksidasi lipid. Berdasarkan hasil penelitian efektivitas antioksidan daun kari sangat dipengaruhi oleh suhu dan waktu pengeringan. Husni et al. (2019) melaporkan suhu dan lama waktu pengeringan Padina sp. memengaruhi aktivitas antioksidan. Aktivitas antioksidan pada produk pangan sangat dipengaruhi oleh beberapa faktor di antaranya konsentrasi antioksidan dan suhu (Sayuti \& Yenrina 2015). Peningkatan suhu dapat meningkatkan proses oksidasi lemak (Gordon 1990). Stabilitas antioksidan sangat dipengaruhi oleh suhu selama proses pengolahan (Coppen 1983).

Berdasarkan hasil penelitian bilangan TBA keumamah loin dengan penggunaan daun kari $10 \%$, suhu $40^{\circ} \mathrm{C}$ dan waktu 8 jam menghasilkan nilai sebesar $0,40 \pm 0,03 \mathrm{mg}$ malonaldehida $/ \mathrm{kg}$ yang mengindikasikan produk masih dapat diterima, yaitu batas terima nilai TBA maksimal $1 \mathrm{mg}$ malonaldehida/kg (Lawrie 2003).

\section{KESIMPULAN}

Perlakuan ekstrak cair daun kari, suhu dan waktu pengeringan tidak memengaruhi karakteristik mutu proksimat dan aktivitas air $\left(a_{w}\right)$, namun sangat berpengaruh dalam menghambat terjadinya proses oksidasi lipid pada produk keumamah loin. Perlakuan terbaik dalam pembuatan keumamah loin adalah menggunakan ekstrak daun kari 10\%, suhu $40^{\circ} \mathrm{C}$ dan waktu 8 jam.

\section{UCAPAN TERIMA KASIH}

Penulis mengucapkan terima kasih kepada Pemerintah Aceh melalui Badan Pengembangan Sumber Daya Manusia (BPSDM), atas bantuan beasiswa "Aceh Carong" di lingkup Aparatur Negeri Sipil (ASN) daerah.

\section{DAFTAR PUSTAKA}

Abeyshinghe DT, Kumara KAH, Kaushalya KAD, Chandrika UG, Alwis DDDH. 2021. Phytochemical screening, total polyphenol, flavonoid content, in vitro antioxidant and antibacterial activities of Sri Langka varieties of Murraya koenigii and Micromelum minutum leaves. Journal of Heliyon. 7: 1-7.

Adawiyah R.2007. Pengolahan dan Pengawetan Ikan. Jakarta(ID): Bumi Aksara.

Apriyantono A, Fardiaz D, Puspitasari NL, Yasni S, Budijanto S. 1989. Petunjuk Laboratorium Analisis Pangan. Bogor (ID): Departemen Pendidikan dan 
Kebudayaan, Pusat antar Universitas Pangan dan Gizi, Institut Pertanian Bogor.

[AOAC] Association of Official Analytical Chemist. 2005. Official Method of Analysis of The Association of Official Analytical of Chemist. Arlington, Virginia (US): The Association of Official Analytical Chemist. Inc.

Baskaran C, Bai VR, Kanimozhi D. 2011. Screening for antimicrobial activity and phytochemicl analysis of various leaf extract of Murraya koenigii. Interinational Journal of Research in Ayurveda and Pharmacy. 2(6): 1807-1810.

Belitz HD, Grosch W, Schiberle P. 2009. Springer Food Chemistry. 4th revised and edition. Annual Review Biochemistry. 79: 655-681.

Biswas AK, Chatli MK, Sohoo J. 2012. Antioxidant potensial of curry (Murraya koenigii) and mint (Mentha spicata) leaf extracts and their effect on colour and oxidative stability of raw ground pork meat during refrigeration storage. Food Chemistry. 133: 467-472.

Comaposada J, Arnau J, Pakowski Z. 2005. On-line determination of water activity at the lean surface of meat products during drying and its relationship with the crusting development. Journal International. 23(8): 1641-1652.

Coppen PP. 1983. The use of antioksidant. Di dalam: J.C. Allen and R.J. Hamilton (Eds.). Rancidity in foods. London (UK): Apllied Science Publisher.

Das AK, Rajkumar V, Dwivedi DK. 2011. Antioxidant effect of curry leaf (Murraya koenigii) powder on quality of ground and cooked goat meat. Food Research International. 18: 563-569.

[DKP] Dinas Kelautan dan Perikanan. 2019. Data Statistik Hasil Perikanan Tangkap Aceh. Aceh (ID): Dinas Kelautan dan Perikanan Aceh.

[DKP] Dinas Kelautan dan Perikanan. 2020. Data Statistik Hasil Perikanan Tangkap Aceh. Aceh (ID): Dinas Kelautan dan Perikanan Aceh.

[DKP] Dinas Kelautan dan Perikanan. 2021. Data Hasil Produksi Pengolahan Ikan.
Aceh (ID): Dinas Kelautan dan Perikanan Aceh.

Dewi NWOAC, Puspati NM, Swantara IMD, Asih IARA, Rita WS. 2014. Aktivitas antioksidan senyawa flavonoid ekstrak etonol biji terong belanda (Solanum betaceum) dalam menghambat reaksi peroksidasi lemak pada plasma darah tikus wistar. Indonesian E-Journal of Applied Chemistry. 2(1): 7-16.

Dina A, Rukmiasih, Suryati T. 2018. Karakteristik dan organoleptik salted egg sauce dengan kosentrasi daun kari yang berbeda [Skripsi]. Bogor (ID): Institut Pertanian Bogor.

Fachraniah, Kurniasih E, Novilasi DT. 2012. Ekstraksi antioksidan dari daun kari. Jurnal Reaksi of Science and Technology.10(21): 35-44.

Fardiaz S.1992. Mikrobilogi Pangan I. Jakarta: Gramedia Pustaka Utama

Gordon MH. 1990. The mechanism of antioxidant action in vitro. In: Hudson BJF (Eds). Food Antioxidants. London (UK): Elsevier Applied Food Science Series, Springer.

Hadiwiyoto. 1993. Teknologi Hasil Perikanan. Jilid 1. Yogyakarta (ID): Liberty

Hernando D, Septinova D, Adhianto K. 2015. Kadar air dan total mikroba pada daging sapi di tempat pemotongan hewan (TPH). Lampung. Jurnal Ilmiah Peternakan Terpadu. 3(1): 61-67.

Husni A, Putra RD, Lelena IYB. 2014. Aktivitas antioksidan Padina sp. pada berbagai suhu dan lama pengeringan. Jurnal Pascapanen dan Bioteknologi Kelautan dan Perikanan. 9(2): 165-173.

Jakhar S, Gahlawat DK, Dahiya S, Swami U, Verma M, Dahiya P. 2015. Antibacterial and antioxidant potential of leaf and seed extracts of Murraya koenigii (Linn.) British Microbiology Research Journal. 10(6): 1-7.

[KKP] Kementerian Kelautan dan Perikanan. 2018. Laporan Kinerja Kementerian Kelautan dan Perikanan. Jakarta(ID): Kementerian Kelautan dan Perikanan.

Kusnandar F. 2011. Kimia Pangan: komponen makro. Jakarta (ID): Dian Rakyat.

Lawrie RA. 2003. Meat Science. Parakkasi A, 
penerjemah. Jakarta (ID): UI Press.

Nabila L, Tamrin, Isamu KT. 2017. Karakterisasi organoleptik, kimia dan mikrobiologi ikan kayu cakalang (Katsuwonus pelamis) dan ikan kayu tongkol (Euthynnus affinis) yang diproduksi di Kota Kendari. Jurnal Sains dan Teknologi Pangan. 2(3): 530541.

Pietta PG. (2000). Flavonoids as antioxidants. Journal of Natural Products. 63: 10351042.

Pundoko SS, Onibala H, Agustin AT. 2014. Perubahan komposisi zat gizi ikan cakalang (Katsuwonus pelamis L) selama proses pengolahan ikan kayu. Jurnal Media Teknologi Hasil Perikanan. 2(1): 9-14.

Rahmawan. 2001. Prinsip Dasar Pengeringan. Bogor (ID): Jurusan Teknologi Industri Pertanian, Institut Pertanian Bogor.

Restina. 2014. Efektivitas ekstrak daun kari (Murraya koenigii) terhadap daya awet keumamah [Tesis]. Bogor (ID): Institut Pertanian Bogor.

Riansyah A, Supriadi A, Nopianti R. 2013. Pengaruh perbedaan suhu dan waktu pengeringan terhadap karakteristik ikan Asin Sepat Siam (Trichogaster pectoralis) dengan menggunakan oven. FishTech. 2(1): 53-68.

Ulfaturriza Z, Ferasyi TR, Azhar A, Isa M, Rastina T, Nazaruddin. 2019. Pengukuran kadar protein pada tahap pembersihan, perebusan dan pengeringan produk ikan kayu di kecamatan Kuta Alam Banda Aceh. Jurnal Ilmiah Mahasiswa Veteriner. 3(3): 170-174.

Sayuti K, Yenrina R. 2015. Antioksidan Alami dan Sintetik. Padang (ID): Andalas University Press.

Singh HPK, Omre, Sandhya MMS. 2014. Curry leaves (Murraya koenigii Linn. Sprengal)-A Miracle Plant. Indian Journal of Scientific Research. 4(1): 46-52.

Sulaiman I. 2014. Perbandingan metode pengeringan dan jenis ikan pada pengujian organoleptik ikan kayu khas Aceh (keumamah). Jurnal Agroindustri. 4(1): 40-47

Winarno FG. 1991. Kimia Pangan dan Gizi. Jakarta (ID): Gramedia Pustaka Utama. 